\title{
Effect of Probiotic Lactobacillus sp. Dad13 on Humoral Immune Response of Balb/C Mice Infected with Salmonella typhimurium
}

\author{
Ika D yah Kusumawati ${ }^{2}$ Eni Harmayani' and Widya A smara ${ }^{x}$
}

\begin{abstract}
1. Reaserch Center for Biotechnology, Gadjah Mada University, Yogyakarta, Indonesia.
2. Faculty of A griculture Technology, Gadjah Mada University, Yogyakarta, Indonesia.

3. Faculty of Veterinary Medicine, Gadjah Mada University, Yogyakarta, Indonesia.
\end{abstract}

\begin{abstract}
A bstract
An indigenous strain of lactic acid bacterium (LAB) identified as Lactobacillus spp. Dad13 (Dad13), isolated from traditional fermented buffalo milk, was found to be potential as probiotic. Theaim of this research was to study the effect of probiotic Dad13on humoral immuneresponse of Balb/ C miceinfected with Salmonella typhimurium. The specific objectivewas to find out the effect of differentDad13consumption time (beforeand along with infection of $S$. typhimurium) on the humoral immuneresponseof Balb/ C mice. Theexperiment was conducted by in vivo trial on 20 males of Bal b/ C mice, age of 6-8 weeks, fed with AIN-93 standard diet. The mice were assigned into 4 groups. Each group received the following treatments, ie. Dad13 only, Dad13 before infection, Dad13 along with infection and Salmonella infection only. A volume of $100 \mu \mathrm{l}$ Dad13 cell suspensions ( $10^{\circ} \mathrm{CFU} / \mathrm{ml}$ ) were given by oral forced feeding daily for a week, at week 3 for group before infection and at week 4 for group of Dad13 only and Dad 13 along with infection. Salmonella infection ( $10 \mathrm{CFU} / \mathrm{ml}$ ) was given once orally at week 4 to all groups except group treated with Dad13 only. The humoral immune response of Balb/ $\mathrm{C}$ mice was detected 2 weeks after infection by measuring the titers of IgG and IgA specific from serum and mucosal intestinal liquid samples using Enzyme linked Immunosorbent A ssay (ELISA) method. Theresultindicated that humoral immuneresponseof Balb/ C miceconsuming Dad13before and along with Salmonella infection were significantly different $(p<0.05)$. Dad13 consumption along with Salmonella infection increased circulated IgG and IgA as well as secretory IgA. It can beconcluded that Dad13 probiotic feeding along with infection increased humoral immuneresponsemoresignificantly compared to that beforeinfection.
\end{abstract}

Key words: Probiotic, Lactobacillus sp. Dad13, Immuneresponse, Salmonella typhimurium

\section{Introduction}

Food borne Salmonellosis is still a big problem in Indonesia. Salmonella typhimurium is one of the pathogenic Salmonella species which causes the diseases. Besides the treatment with antibiotics, functional food such as probiotic iscurrently considered as an alternativeway to reduce the number of diarrhea cases which are caused by food contamination. Probiotic gives health effect by improving

Corresponding author: Widya Asmara, Research Center for Biotechnology, Gadjah Mada University, JI. Teknika Utara, Barek, Sleman Yogyakarta, 55281. Tel: 62-274-564305; Fax: 62-274-520842; E-mail: wied_as@ugm.ac.id the microbial balance of gastrointestinal tract (Perdigon et al., 1995; Kaminogawa et al., 2004). Probiotic is defined as live microorganism added to food that give benefit to host by increasing the microbial balance of intestinal (Ziemer et al., 1998). Another definition stated that probiotic is live microorganism which is consumed by oral and give health effect (Losada et al., 2002; Champagne et al., 2005). Some lactic acid bacteria (LAB) have been studied as potent probiotic.

Current researchs of probiotic focus on the capability of the products to increase immune system and immune response mechanism which is thought to play an important role to protect the body from any 
kind of pathogen infection. Studies on the effect of probiotic on the immune system involved the usage of experimental animal, especially mice as a model (Tejada-Simon et al., 1999; Sheih et al ., 2001; Sgouras et al ., 2003; LeBlanc, et al., 2004) and most of the result could beadopted to human (Perdigon et al ., 1995). The immune evaluation is conducted on the parameter that represent innate immunity and acquired immunity, as systemicimmunity or humoral immunity.

A $n$ indigenous strain of Lactobacillus spp. Dad13 (Dad13) which was isolated from traditional fermented buffalo milk (N gatirah, 2000), was recommended as a potent probiotic. Theaim of thisstudy was to identify the effect of the Dad13 on humoral immune response of Balb/ $\mathrm{C}$ mice infected with Salmonella typhimurium. The specific objective was to find out the effect of different consumption time of Dad13 (before and along with Salmonella infection) on the humoral immuneresponse.

\section{M aterials and M ethods}

\section{Bacterial strains, growth condition and cell suspension.}

Lactobacillus spp. Dad13 obtained from Dr. Eni Harmayani (Food Nutrition Culture Collection, GMU) was maintained in MRS (Man Rogosa de Sharpe) broth medium (Oxoid) and grown to end of log phase at $37^{\circ} \mathrm{C}$ for $16 \mathrm{~h}$, using an overnight culture. The number of cells were determined by plate count method serial dilution in $0.1 \%$ peptone water on MRS agar (Oxoid) incubated at $37^{\circ} \mathrm{C}$ for $24-48 \mathrm{~h}$. Salmonella typhimurium (Food Nutrition Culture Collection/ FNCC 157) was grown with agitation (120 rpm) in TSB (Tryptic Soy Broth) medium (Oxoid) to end of log phase at $37^{\circ} \mathrm{C}$ for $18 \mathrm{~h}$, using an overnight culture. The number of cells were determined by plate count method serial dilution in $0.1 \%$ peptone water on SS (Salmonella shigella) agar (Oxoid) incubated at $37^{\circ} \mathrm{C}$ for $24-48 \mathrm{~h}$.
Cell suspensions of Dad13 and Salmonella were prepared by resuspended in sterile phosphate-buffered solution (PBS) of $\mathrm{pH} 7.0$ to the desired concentration of $10 \mathrm{CFU} / \mathrm{ml}$ for Salmonella and $10^{\circ} \mathrm{CFU} / \mathrm{ml}$ for Dad 13.

\section{Standard diet AIN -93.}

Standard AIN-93 diet for the experimental animals was prepared according to Reeves et al. (1993). The materials (Table 1) starting from the lowest amount added by sufficient water to dilute and mix the materials. The mixture was shaped and dried in a cabinet dryer (40$\left.60^{\circ} \mathrm{C}\right)$.

Table 1. Composition of standard diet AIN-93 (gr/ 1000gr)

\begin{tabular}{clc}
\hline No & Componen & Quantity(gram) \\
\hline 1 & Maizena & 620.7 \\
\hline 2 & Casein & 140.0 \\
\hline 3 & Sucrose & 100.0 \\
\hline 4 & Soybean oil & 40.0 \\
\hline 5 & Cellulose & 50.0 \\
\hline 6 & Mineral mix, MX AIN-93 & 35.0 \\
\hline 7 & Vitamin mix, VX AIN-93 & 10.0 \\
\hline 8 & Kholin bitartrat & 2.5 \\
\hline 9 & L-cystin & 1.8 \\
\hline Quantity & 1000.0 \\
\hline
\end{tabular}

Immune system stimulation studies.

The immunomodulatory effect of Dad13 was determined by in vivo trial on Balb/ C mice infected with Salmonella typhimurium (Unit for Experimental Animal Development, Integrated Research and Testing Laboratory-GMU). Twenty males of Balb/ C mice (age of 6-8 weeks, 10-19 g weight each) were obtained from Biotechnology Research Centre-GMU. The mice were acclimated for 2 weeks and divided randomly into 4 groups. Each group (5 mice) received the following treatments : Dad13 only (DWI); Dad13 before infection (DBI); Dad13 along with infection (DAI) and Salmonella infection only (IWD) (Figure 1). Throughout the experiment the mice were fed with standard diet $5 \mathrm{~g} /$ day and water ad libitum (Kusumawati, 2005). 


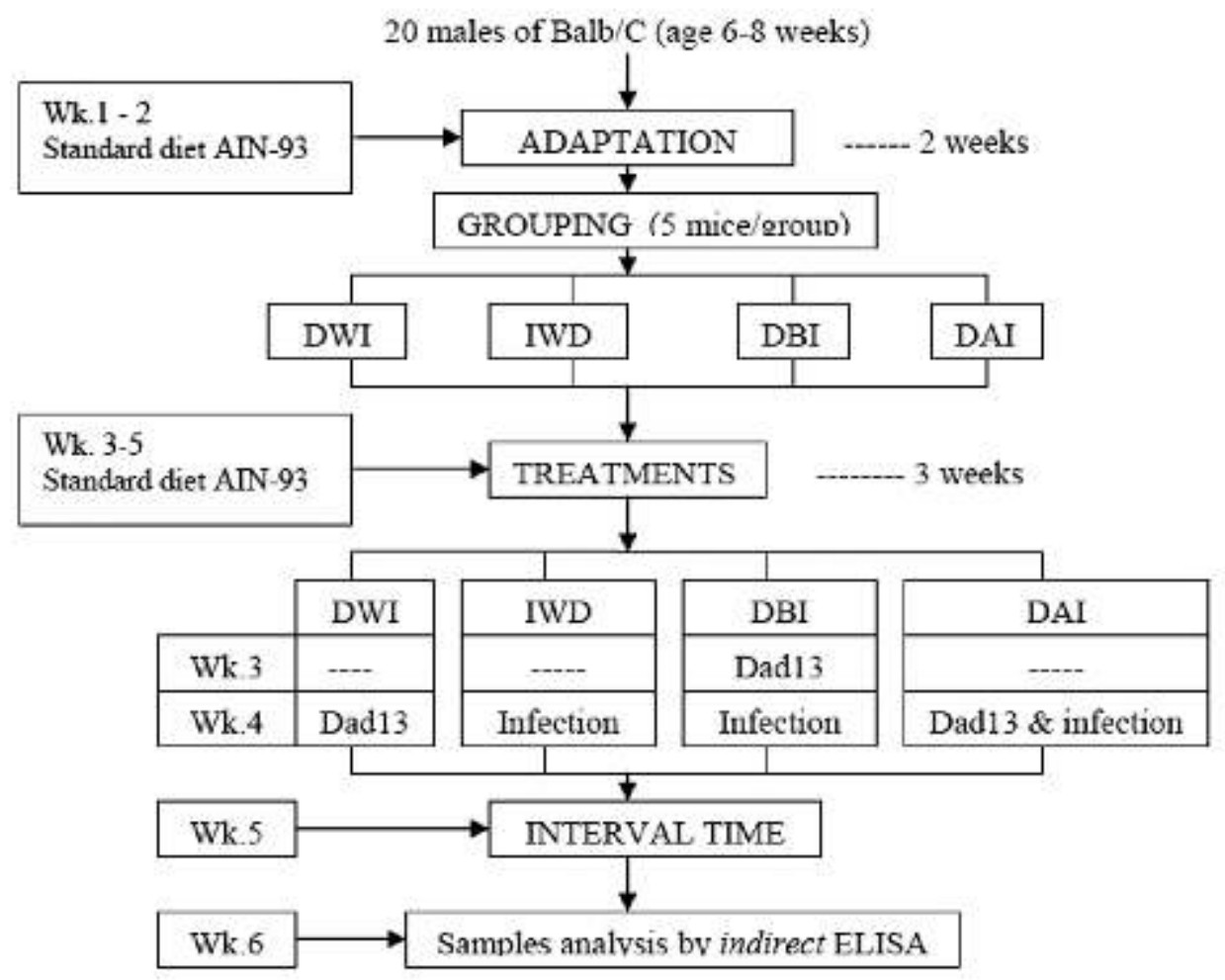

A volume of $100 \mu \mathrm{l}\left(10^{\circ} \mathrm{CFU} / \mathrm{ml}\right)$ of Dad 13 cell suspensions were given daily by oral forced feeding for a week, at week 3 for group of Dad13 beforeinfection (DBI) and at week 4 for group of Dad13 only (DWI) and Dad13 along with infection (DAI). Salmonellainfection (10CFU/ ml) wasgiven once orally at week 4 (day 23) to all groups except group treated with Dad13 only (DWI).

\section{Indirect ELISA}

The humoral immune response of Balb/ C mice was detected 2 weeks after infection by measuring the titers of IgG and IgA specificto Salmonella sp. from serum and mucosal intestinal liquid samples using
DWI : Dad13 only without infection IWD : Infection Salmonella only DBI : Dad13 before infection DAI : Dad13 along with infection indirect ELISA (Enzyme-linked Immunosorbent A ssay) method. Some stages were done for ELISA, starting from antigen preparation, antibody isolation, and detection of IgG/IgA specific using indirect ELISA (A usubel et al., 1995).

\section{Antigen preparation}

Total crude protein S. typhimurium was used as an antigen. The antigen was prepared by centrifugation and sonication of bacterial culture. A portion of $100 \mathrm{ml}$ Salmonella culture in TSB medium was centrifuged $(1200 \mathrm{~g})$ at $4^{\circ} \mathrm{C}$ for $10 \mathrm{~min}$. Cell pellet was resuspended in sterile PBS of $\mathrm{pH}$ 7.0 and centrifuged. Thepellet was washed 3 times. Then the pellet was resuspended in 2 
$\mathrm{ml}$ of PBSand sonicated 5 timesfor $30 \mathrm{~s}$. Then the supernatant was removed and stored at $20^{\circ} \mathrm{C}$ until used as coating for ELISA (A usubel et al ., 1995; A dytianingsari, 2004).

\section{Antibody isolation}

Approximately $0.5 \mathrm{ml}$ of mice blood samples were bleed from retroorbital using micro-hematocrit. All mice were subsequently sacrificed by cervical dislocation and aseptically dissected. The entire stomach was dissected and the intestine (before and after caecum) which contained Peyer's patches was recovered (Adytianingsari, 2004). The distance from first Peyer's patch until caecum was approximately $25 \mathrm{~cm}$, so the intestine was cut in the distance of $30 \mathrm{~cm}$ from caecum. Antibody samples were prepared from serum and mucosal intestinal liquid. Serum samples were recovered from centrifugation $(1000 \mathrm{~g})$ of blood samples at $4^{\circ} \mathrm{C}$ for $15 \mathrm{~min}$. Serum was stored at $-20^{\circ} \mathrm{C}$. Mucosal intestinal samples wereflushed with $5 \mathrm{~mL}$ of PBS pH 7.0 and particulate material was removed by centrifugation ( $10000 \mathrm{~g}$, for 10 $\min$, at $4^{\circ} \mathrm{C}$ ). The remaining supernatant fluid was stored in triplicate at $-20^{\circ} \mathrm{C}$. Both serum and intestinal fluid were used to measure the antibody IgG/IgA concentration (LeBlancet al., 2004).

\section{Detection of specific IgG/I gA}

Firstly, checker board ELISA was done to calibrate and optimize ELISA procedure of crude protein of S.typhimurium antigen and antibody from samples (serum and intestinal liquid) for measuring IgG/ IgA concentration. Checker board gave result on cut off point value upon dilution of samples. The cut off point valuewas used as a basis for samples detection by indirect ELISA. Antigen protein S. typhimurium (100 $\mu \mathrm{l} /$ well) in buffer coating of $0.2 \mathrm{M}$ carbonatebicarbonate buffer $(\mathrm{pH} 10.6)$ was coated on 96-well flat-bottomed microplates (Maxishop, Nunc) with concentration 5 $\mu \mathrm{g} / \mathrm{ml}$. The microplates were incubated at $37^{\circ} \mathrm{C}$ over night in water bath. The plates were then washed 3 times with $200 \mu \mathrm{l} /$ well washing buffer $(0.15 \mathrm{M} \mathrm{N} \mathrm{aCl}$; 0.05 TritonX100; $0.02 \% \mathrm{NaN} 3$ ) and blocked with 200 $\mu \mathrm{l} /$ well for $1 \mathrm{~h}$ at $37^{\circ} \mathrm{C}$ with PBS of $\mathrm{pH} 7.0$ containing 1\% BSA. Plates were washed 3 times with $200 \mu \mathrm{l} /$ well washing buffer and incubated for $1 \mathrm{~h}$ at $37^{\circ} \mathrm{C}$ with $100 \mu \mathrm{l} / \mathrm{well}$ primer antibody of serum (diluted $1 / 10$ in incubation buffer) or intestinal liquid (without dilution), both of them were added in duplicate. The control was conducted by replacing samples with $100 \mu \mathrm{l} /$ well incubation buffer. Then plates were washed again 3 times with $200 \mu \mathrm{l} /$ well washing buffer and incubated for $1 \mathrm{~h}$ at $37^{\circ} \mathrm{C}$ with 100 $\mu \mathrm{l} /$ well goat anti mouse IgG/lgA alkaline phosphatase conjugated (diluted at 1/ 3000). A fter incubation, plateswerewashed 3times with $200 \mu \mathrm{l} /$ well washing buffer and added with $150 \mu \mathrm{l} /$ well buffer substrate (4$\mathrm{N}$ itrophenil phosphate in substrate buffer $\mathrm{pH}$ 9.6) then incubated for $30 \mathrm{~min}$ at $37^{\circ} \mathrm{C}$. The optical density (OD) was read at $405 \mathrm{~nm}$ using ELISA reader (Benchmark-Bio-rad).

\section{Statistical analysis}

The data were subjected to analysis of variance with SPSS software version 10. LSD (Least Significant Difference) was used to compare the least square means of all treatments with $\alpha<0.05$. Results were expressed as the mean of log titer antibody (Loon and Veen, 1980).

\section{Results and Discussion}

The effect of Dad13 consumption on Balb/ C mice in this research was focused on humoral immune response which is mediated by antibody. The titers of IgG and IgA as detected by indirect ELISA (Ausubel et al., 1995). 
The result indicated there was an increase of circulating IgG of Bal b/ C miceas an effect of treatment with probiotic Lactobacillus Dad13 (Table 2). However, there were no significantly difference ( $p>0.05$ ) of IgG serum among 3 treatment groups : Dad13 only without infection (log titer $=2.4$ ), Dad13 along with infection (log titer $=2.5$ ), and Salmonella infection only (log titer $=2.0$ ). Group which consumed Dad13 before infection (log titer $=1.7$ ) was significantly different $(p<0.05)$ with group consumed Dad13 along with Salmonella infection. It showed that humoral immune response of Balb/ C mice was affected by different consumption timeof Dad13.

Table 2. Log10 titer IgG circulation Balb/ C mice

\begin{tabular}{lc}
\hline TreatmentG roup & $\begin{array}{c}\text { Log10titer } \\
\text { circulated IgG* }\end{array}$ \\
\hline Dad13only withoutinfection(DWI) & 2.4 \\
\hline Infection Salmonella only (IWD) & $2.0^{\circ}$ \\
\hline Dad13beforeinfection(DBI) & $1.7^{\circ}$ \\
\hline Dad13along with infection(DAI) & 2.5 \\
\hline
\end{tabular}

*Different supercript showed significantly different $(\alpha<0.05)$ between grup.

The difference on humoral immune response might related with the factor of different value of imunogenic factor of antigen which entering the body of Balb/ C mice, between Dad13cell and Sal monella cell. Lactobacillus Dad13 belong to Gram positive bacteria. Peptidoglycan is part of $50 \%$ of all cell wall of Gram positive bacteria. The main component of cell wall bacteria is mostly as teichoic and theichuronic acid with percentage until $50 \%$ dried cell weight of cell wall and $10 \%$ of total dried cell. Teichoic acid is the main component of outer antigen (Ag) from Gram positive species (Brooks et al., 2001). The capability of probiotic to stimulate immune system is very related with amount of peptidoglycan and lypopolisaccharide from cell wall composition (Widodo, 2003). That is the reason why Dad13 as probiotic was given in the form of cell suspension in media and not in theform of supernatant.

While Salmonella cell was Gram negative bacteria. This kind of bacteria have thinner peptidoglycan layer than Gram positive. Cell wall of Gram negative bacteria consist of 3 components, ie. lipoprotein, outer membrane and lipopolysaccharide (LPS). Lipoprotein is dominated protein of Gram negative with function to stabilize outer membrane and stick on peptidoglycan. Outer membrane is composed of LPS molecule which called as endotoxin of Gram negative bacteria due to its capability to stick on the outer cell and flowing out when cell lysis. Polysaccharide is the biggest part of Ag (Brooks et al ., 2001). Due to this reason Salmonella infection was conducted orally by giving Salmonella cell suspension which was still composed of antigenicand virulent cell wall.

The two groups of DBI (Dad13 before infection) and DAI (Dad13 along with infection) received both of Dad13 and Salmonella infection with different time of Dad13 consumption and resulted on significantly different of humoral immune response. It was indicated that the different time of giving probiotic gave effect to the immune system. Giving two types of antigens in the same time result in giving bigger immune response, better than giving two antigens in the different time, one by one. Two particles of antigen have bigger moleculeweight than just oneantigen. Klein cit Nurliyani (2003) stated that protein immunogenicity was effected by its moleculeweight, thelarger moleculeweight of protein themoreimmunogenic.

The same phenomenon on IgG circulation was observed. Humoral immune response of two different Dad13 consumption time (before and along with 
Salmonella infection) were also significantly different $(p<0.05)$ in two other parameters, circulating IgA from serum and secretory of IgA from intestinal fluid (Tabel 3 and 4). Consumption of Dad13 for a week without infection (100 ml, 10* CFU/ ml/ day) increased circulated IgG/ IgA and secreted IgA as compared to feeding Dad13 before Salmonella infection (100ml, 10 CFU/ $\mathrm{ml}$ ).

Table3. Log10titer IgA circulation Balb/ C mice

\begin{tabular}{ll}
\hline Treatment G roup & $\begin{array}{l}\text { Log10 titer } \\
\text { circulated IgA* }\end{array}$ \\
\hline Dad13 only without infection (DWI) & $2.3 \mathrm{~b}$ \\
\hline Infection Salmonella only (IWD) & $2.3 \mathrm{~b}$ \\
\hline Dad13 before infection (DBI) & $1.7 \mathrm{a}$ \\
\hline Dad13 al ong with infection(DAI) & $2.3 \mathrm{~b}$ \\
\hline
\end{tabular}

*Different supercript showed significantly different $(a<0.05)$ between grup.

Table 4. Log10 titer IgA secretion Balb/ C mice

\begin{tabular}{ll}
\hline Treatment G roup & $\begin{array}{l}\text { Log10 titer } \\
\text { secreted IgA* }\end{array}$ \\
\hline Dad13 only without infection (DWI) & $1.2 \mathrm{ab}$ \\
\hline Infection Sal monella only (IWD) & $1.4 \mathrm{~b}$ \\
\hline Dad13 before infection (DBI)1.0a & \\
\hline Dad13 along with infection(DAI) & $1.4 \mathrm{~b}$ \\
\hline
\end{tabular}

*Different supercript showed significantly different $(a<0.05)$ between grup.

Feeding of Dad13 before infection did not give result as preventive agent from Salmonella. Dad13 might only colonize temporary in the intestine, so that there was no enough barrier to prevent Salmonella colonization that given after Dad13 consumption. The pathogenicity of Salmonella might also affect on decreasing of Ig concentration of Balb/ C mice. According to Tejada-Simon et al . (1999), mice fed with yogurt supplemented with Lactobacillus acidophilus and Bifidobacteria and infected with Colera-toxin gave response on IgG serum, but not significantly differentfrom control.

Effect of increased of IgG specific Salmonella during the research was detected in the serum 2 weeks after infection. Birge (1992) stated that immune response by antibody secretion needs timeinterval for its mechanism. An antigen that gave in the first time would induce primary immune response, by secreting specific antibody to an antigen. Increasing of the specific antibody molecule lasted for a few days, reached the peak in the 10-20 days, then decreased to lowest concentration after 30 days. IgG is dominant antibody in the secondary response and build the barrier to fight bacteria and virus (Brooks et al., 2001). IgG is the main component in serum imunoglobulin, with the molecule weight of 160,000 Dalton. Its concentration is 13 $\mathrm{mg} / \mathrm{ml}$ and as $75 \%$ component of all imunoglobulin (Baratawidjaja, 2002). IgG consists of 4 sub class (IgG1 until IgG4) and havehalf timeof 23days (Brooks, et al., 2001).

Feeding Dad13 only to Balb/ C mice gave effect on increased IgG and this effect increased significantly if in the same time infection was also given to the mice. This indicated that Dad 13 could act as stimulator of IgG serum but not as preventive agent. The increased of IgA (serum and intestinal fluid) was not detected as theeffect of Dad13 consumption compare to group treated with Salmonella infection within 2 weeks after infection. Dad13 could not act as stimulator as well as preventiveagent of IgA serum and IgA secretion. IgA is found in thetwo forms, IgA serum and IgA secretion which is the biggest part. The molecule weight of IgA is 165,000 Dalton (Baratawidjaja, 2002). IgA consists of 2 sub class (IgA 1 and $\operatorname{IgA} 2)$ and half timeof 14days (Brookset al ., 2001). 
Oral feeding of Dad13 as probiotic firstly might gave initial induction on humoral immune response of stomach mucose of Balb/ C mice, then within 14 days after Sal monella infection, Ig precursor might have circulated in the blood which ended in lamina propria. In the blood, IgG plasm cell were existed in bigger number than IgA plasm cell. This agreed with the result of this research, circulated IgG titer (log titer $=1.7$ 2.5) was higher than circulated IgA (log titer $=1.7-2.4$ ) and secreted IgA (log titer $=1.0$ 1.4). Theasumption that $L A B$ increased local immunity of gastrointestinal by induction/ infection (Puri et al., 1996) was not truly observed in this research using indigenous strain of Dad13 after 14 days of infection. Dad13 could not act as preventive agent as well as stimulator agent of slgA (secretion IgA) mucose intestinal fluid $\mathrm{Balb} / \mathrm{C}$ mice. Some factors related with optimum doses of consumption, strain-host specific, individu variability also time secretion of antibody were still in questioned.

\section{Conclusion}

Consumption of Lactobacillus Dad13 before and along with Salmonella typhimurium infection give significantly different $(p<0.05)$ result. Dad13 consumption along with Salmonella infection increased circulating IgG and IgA also secretory IgA. Feeding of Dad13 probiotic along with infection increased humoral immune response more significantly compareto that beforeinfection.

\section{References}

Adytianingsari, P., 2004. Produksi IgA pada mencit setelah imunisasi peroral menggunakan verocytotoxigenic $E$. coli O157:H 7 (VTEC O157:H 7) dengan dan tanpa incomplete Freund's adjuvants (IFA). Tesis. Pasca Sarjana
UGM, Yogyakarta.

Ausubel, F.M., Brent, R., Kingston, R.E., Moore, D.D., Seidman, J.G., Smith, J.A., and Struhl, K., (eds), 1995. Immunology. Short protocols in molecular biology. 3-eds. USA: John Wiley and Sons, Inc.

Baratawidjaja, K.G. ed., 2002. Imunologi D asar. 5-eds. Jakarta, Indonesia: Balai Penerbit Fakultas Kedokteran Universitas.

Brooks, G.F., Butel, J.S. and Morse, S.A., 2001. M ikrobiologi Kedokteran. In Mudihardi, E., Kuntaman, Wasito, E.B., Mertaniasih, N.M., Harsono, S. and A limsardjono, L. (eds). Indonesia: PenerbitSalembaM edika.

Champagne, C.P. and Gardner, N.J., 2005. Challenges in the addition of probiotic cultures to foods. Critical Reviews in Food Scienceand N utrition, 45 (1), 61-80.

Kaminogawa, S., dan Nanno, M., 2004. Modulation of immune functions by foods. Evidence-based complementary and alternative medicine (eCAM). Oxford: Oxford University Press., 1 (3), 241-250.

Kusumawati, D., 2004. Bersahabat Dengan H ewan Coba. 1* ed. Yogyakarta: Gadjah MadaUniversity Press.

LeBlanc, J., Fliss, I. and Matar, C., 2004. Induction of a humoral immune response following an Escherichia coli 0157:H7 infection with an immunomodulatory peptidic fraction derived from Lactobacillus helveticusfermented milk. Clinical and Diagnostic Laboratory Immunology, American Society for Microbiology. 1171-1181.

Loon, A.V. and Veen, J.V., 1980. Enzymelinked immunosorbent assay for quantitation of toxoplasma antibodies in human sera. J. Clin. Pathol. 33, 635639. 
Losada, M .A ., and Olleros, T., 2002. Towards a healthier diet for the colon : the influence of fructooligosaccharides and lactobacilli on intestinal health. $\mathrm{N}$ utr. Research, 22, 71-84.

Ngatirah, 2000. Seleksi Bakteri A sam Laktat sebagai Agensia Probiotik yang Berpotensi Menurunkan Kolesterol. Tesis. Program Studi IImu dan Teknologi Pangan. Pasca Sarjana UGM, Yogyakarta.

Nurliyani, Artama, W.T. and N oor, Z., 2003. Sifat imunomodulator protein susu kuda pada respon imun humoral mencit. Proseding Seminar $\mathrm{N}$ asional dan Pertemuan Tahunan Perhimpunan Ahli Teknologi Pangan Indonesia (PATPI). Peranan Industri dalam Pengembangan Produk Pangan Indonesia. Yogyakarta, 22-23Juli 2003.

Perdigon, G., Alvarez, S., Rachid, M., Agüero, G. and Gobbato, N., 1995. Symposium: Probiotic bacteria for humans : Clinical systems for evaluation of effectiveness. Immune system stimulation by probiotics. J. D airy Sci., 78, 1597-1606.

Puri, P., Rattan, A., Bijlani, R.L., Mahapatra, S.C. and Nath, I., 1996. Splenic and intestinal lymphocyte proliferation response in mice fed milk or yogurt and challenged with Salmonella typhimurium. Int. J.Food Sci. N utr., 47, 391-398.

Reeves, P. G., N ielssen, F.H . and Fahey, G.C., 1993. AIN-93 purified diets for laboratory rodents: final report of the American Institute of Nutrition Ad Hoc Writing Committee On The Reformulation of the AIN-76A Rodent Diet. J. N ut. 123, 1939-1951.

Sgouras, D., Maragkoudakis, P., Petraki, K., Martinez-Gonzalez, B., Eriotou, E., Michopoulos, S., Kalantzpoulos, G.,
Tsakalidou, E. and Mentis, A., 2004. In vitro and in vivo inhibition of H elicobacter pylori by Lactobacillus casei strain Shirota. A ppl. Environm. M icrob., 70, (1), 518-526.

Sheih, Y., Chiang, B., Wang, L., Liao, C. and Gill, H.S., 2001. Systemic immunityenhancing effects in healthy subjects following dietary consumption of the lactid acid bacterium Lactobacillus rhamnosus HN 001. J. A m. Coll. N utr., 20 (2), 149-156.

Tejada-Simon, M.V., Lee., J.H., Ustunol, Z. and Pestka, J.J., 1999. Ingestion of yogurt containing Lactobacillus acidophilus and Bifidobacterium to potentiate immunoglobulin $A$ responses to cholera toxin in mice. J. D airy Sci ., 82, 649-660.

Widodo, 2003. Bioteknologi industri susu. 1sted. Yogyakarta: LacticiaPress.

Ziemer, C.J. and Gibson, G.R., 1998. An overview of probiotics, prebiotics and synbiotics in the functional food concept : perspectives and future strategies. D airy J., 8, 473-479. 